\title{
Implications of photodynamic cancer therapy: an overview of PDT mechanisms basically and practically
}

Nafiseh Sobhani ${ }^{1}$ and Ali Akbar Samadani ${ }^{2,3^{*}}$

\begin{abstract}
Background: Tumor eradication is one of the most important challengeable categories in oncological studies. In this account, besides the molecular genetics methods including cell therapy, gene therapy, immunotherapy, and general cancer therapy procedures like surgery, radiotherapy, and chemotherapy, photodynamic adjuvant therapy is of great importance. Photodynamic therapy (PDT) as a relatively noninvasive therapeutic method utilizes the irradiation of an appropriate wavelength which is absorbed by a photosensitizing agent in the presence of oxygen.

Main body of the abstract: In this procedure, a series of events lead to the direct death of malignant cells such as damage to the microvasculature and also the induction of a local inflammatory function. PDT has participated with other treatment modalities especially in the early stage of malignant tumors and has resulted in decreasing morbidity besides improving survival rate and quality of life. High spatial resolution of PDT has attracted considerable attention in the field of image-guided photodynamic therapy combined with chemotherapy of multidrug resistance cancers. Although PDT outcomes vary across the different tumor types, minimal natural tissue toxicity, minor systemic effects, significant reduction in long-term disease, lack of innate or acquired resistance mechanisms, and excellent cosmetic effects, as well as limb function, make it a valuable treatment option for combination therapies.
\end{abstract}

Short conclusion: In this review article, we tried to discuss the potential of PDT in the treatment of some dermatologic and solid tumors, particularly all its important mechanisms.

Keywords: Photodynamic cancer therapy, Mechanisms, Oncological studies, Cancerous tissues and cells

\section{Highlights}

1. The implication of PDT is approved clinically and is a noninvasive therapeutic method that can employ an elective cytotoxic function toward cancerous tissues.

2. The effectiveness of PDT in cutaneous malignancies as a promising treatment modality and in some cases like lung cancer has been proven.

3. Designing methods to overcome constraints such as photosensitivity, poor light penetration, low tumor

\footnotetext{
*Correspondence: a_a_hormoz@yahoo.com

${ }^{3}$ Clinical Research Development Unit of Poursina Hospital, Guilan

University of Medical Sciences, Rasht, Iran

Full list of author information is available at the end of the article
}

selectivity, and systemic toxicity seems to be effective in PDT efficiency.

4. PDT leads to a sequence of photochemical and photobiologic activities that leads to irreversible photo damage to cancerous cells.

\section{Background \\ Main text}

Photochemical treatment of cancer, often called photodynamic therapy (PDT), is a relatively noninvasive method compared with other common cancer therapy modalities in treatment of cancerous small tumors. Using PDT as an adjuvant treatment was recommended in literatures to overcome some obstacles of common monotherapies 
such as surgery, chemotherapy, and radiation therapy $[106,131,134]$. In some researches, high spatial and temporal resolution of PDT has been reported as a functional feature in image-guided PDT [59, 124, 127, 132]. This method is based on the reactions of a photosensitizer in the presence of oxygen molecules and appropriate wavelength of light $[8,74,105]$.

The performance of PDT requires some qualifications including (1) a photosensitizer (PS) with maximum tumor uptake, (2) sufficient elapsed time after injection to achieve most accumulation of the photosensitizer in the tumor, and also (3) irradiation of light with appropriate wavelength to optical destruction of the tumor.

There are two oxidative mechanisms in optical destruction of tumor cells. Photosensitizer interacts with a biomolecule or oxygen, and free radical production occurs as a result of the transfer of electron or hydrogen. Singlet oxygen produces by energy transfer from triplet excitation mode to triplet ground state of oxygen molecule.

Different types of biomolecules such as unsaturated fats, cholesterol, and alpha amino acids such as tryptophan 3 and metanil 6 react with singlet oxygen easily. These compounds are the main components of different biological membranes. So, the membrane damage is an important process which causes the necrosis and destruction of blood vessels through PDT [14]. The photosensitizer usually is injected with aqueous buffer solution or liposome, and light source is often a laser with optical fibers to optimal light transfer to the therapeutic region.

\section{Physics of photodynamic therapy}

Several phenomena such as scattering, reflection, transmission, and absorption may occur after tissue irradiation, which determine the type of effect and depth of penetration in tissue [91].

To perform a biological reaction, photons must first be adsorbed by a photosensitizer, and this is possible when the wavelength of light is the same as the absorption spectrum of the photosensitizer [78]. Intense absorption in the wavelength less than $600 \mathrm{~nm}$ by in vivo pigments (mainly hemoglobin) and less efficiency of singlet oxygen production in the wavelength more than $900 \mathrm{~nm}$ sometimes eliminate the clinical applications to the region of 600-900 nm [78].

\section{Mechanism of competitive reactions in photodynamic therapy}

Following the absorption of a photon with appropriate energy, the photosensitizer molecule is transferred from the ground state $\left(\mathrm{S}_{0}\right)$ to excited state $\left(\mathrm{S}_{1}\right)$ which may return to its primitive ground state along with fluorescence radiation or be transferred to triplet excited state as an inter-system crossing. The triplet state of photosensitizer molecule in the tissue has a relatively long lifespan which can cause changes in surrounding molecules and initiate two competitive reactions called reaction types I and II (Fig. 1) [10, 24].

Reaction type I includes the transfer of electron or proton to oxygen and surrounding molecules to form anionic or cationic radicals. These radicals can react with oxygen molecule to form the reactive oxygen species (ROS). Reaction type I often leads to the formation of superoxide ions by the transfer of one electron to an oxygen molecule. These ions do not act as active ions in biological systems, but they can produce hydrogen peroxide $\left(\mathrm{H}_{2} \mathrm{O}_{2}\right)$, which is easily absorbed from cell membranes. In high concentrations, $\mathrm{H}_{2} \mathrm{O}_{2}$ can react with super oxide molecules caused by the production of hydroxyl as an active radical which has the ability to ionize any molecules with low activation energy.

In reaction type II, the photosensitizer molecule, by transitioning from the triplet state to ground state and transfer of energy to oxygen molecule, converts it to excited singlet oxygen. The singlet oxygen as a chargeless molecule can spread to the cytoplasm and biological membranes. Approximately all of photosensitizers have high quantum yield in this reaction.

Photosensitizers typically produce one singlet oxygen per every two absorbed photons. The available evidences show that the singlet oxygen is the main intermediary of biological damage in PDT. Some studies have shown that the tissue necrosis needs to be $10^{18}-10^{19}$ singlet oxygen per $\mathrm{cm}^{3}$ [122].

Reactions types I and II as direct effects of PDT occur in parallel depending on the type of photosensitizer and the oxygen concentration. It should be noted that for more applied photosensitizers, reaction type II is a dominant process [91].

PDT assists in tumor destruction via apoptosis and necrosis in direct tumor cell killing, hypoxia and starvation of tumor in vasculature damage and T cells, antibodies, and long-term memory immunity in stimulation of the immune system $[69,97]$.

\section{Photosensitizers}

There is no history of photodynamic therapy that can be said without regard to hematoporphyrin. For the first time, Schere produced the impure hematoporphyrin, and its fluorescence spectrum was interpreted by Thudichum in $1867[11,50]$. After the identification of impurity of hematoporphyrin, researches began to find products with higher purity such as tetraphenylporphine sulfonate (TPPS), phthalocyanine (Pc), aluminum phthalocyanine sulfonates (AlPcS), meta hydroxyl-phenyl (mTHPC), and protoporphyrin IX. 


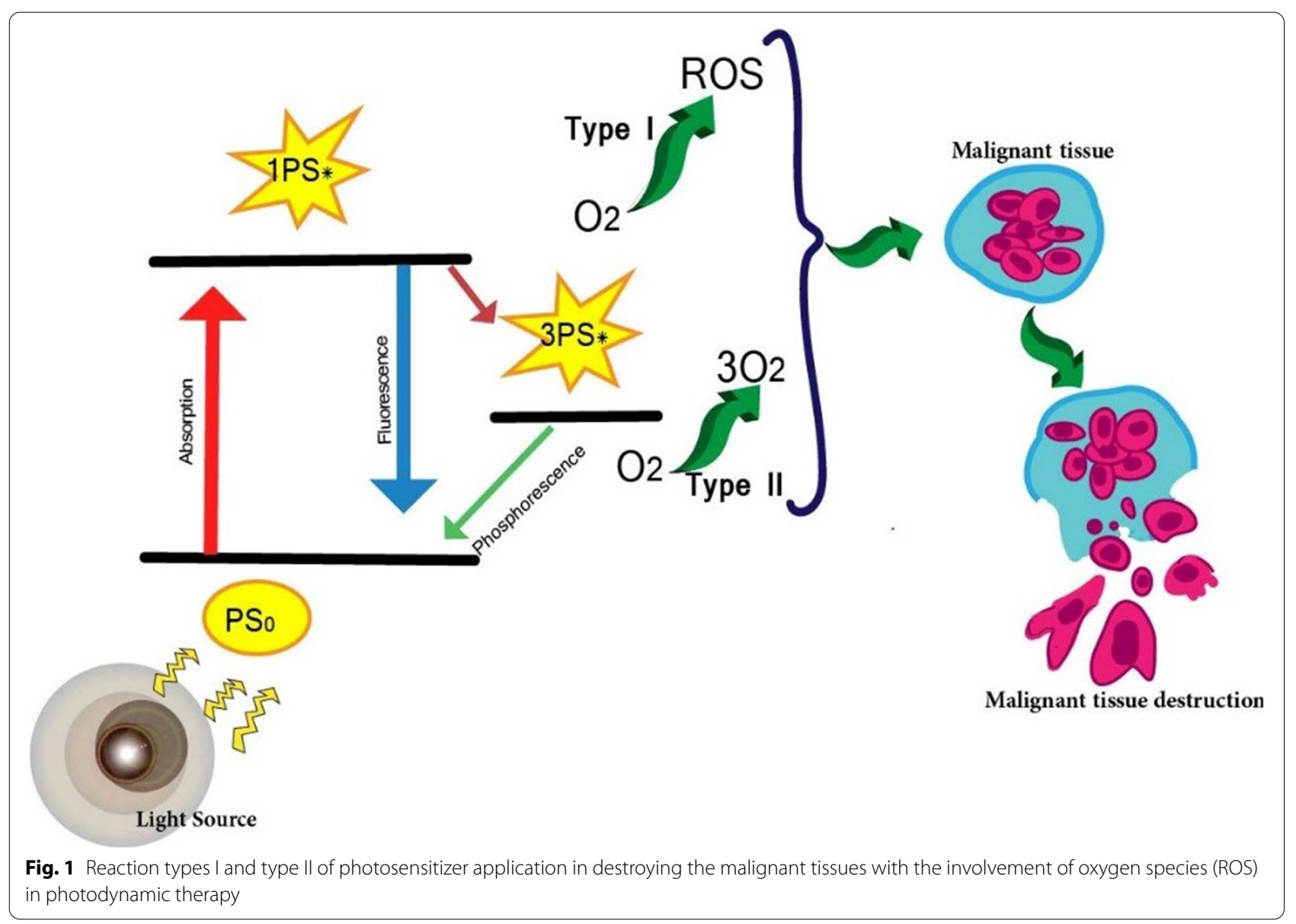

The first attempts to apply PDT in tumor treatment and other skin diseases such as lupus were made by Tappeiner's group in 1903-1905. They intratumorally injected some of useful dyes such as eosin, fluorescein, and sodium dichloroanthracene disulfonate, and satisfactory results were reported. Then, much research have been done on the sensitivity of materials to light which showed that the presence of oxygen is necessary for the occurrence of a photodynamic effect [63].

Primary sensitizers had three main drawbacks: skin sensitization, low selectivity, and poor absorption in infrared region. So, deep tumor treatment was difficult [14]. A suitable photosensitizer should have the following characteristics:

A. Photophysical property: high absorption in the wavelengths of $630-980 \mathrm{~nm}$ to maximum penetration in tissue and minimum absorption in the range of 400$600 \mathrm{~nm}$ which causes photosensitivity by sunlight (Table 1).

B. Photochemical property: high singlet oxygen production to maximum PDT efficiency. Photosensitizer
Table 1 Penetration depth of different wavelengths of light applied in PDT

\begin{tabular}{lll}
\hline Wavelength $(\mathbf{n m})$ & Penetration depth $(\mathbf{c m})$ & Reference \\
\hline NIR region & $<10$ & {$[25]$} \\
$662-780$ & $0.4-1$ & {$[7]$} \\
$597-622$ & $0.3-0.4$ & {$[7]$} \\
$577-597$ & 0.3 & {$[7]$} \\
$492-577$ & 0.2 & {$[7]$} \\
$455-492$ & 0.1 & {$[7]$} \\
$390-455$ & 0.1 & {$[7]$} \\
\hline
\end{tabular}

also must be fluorescent for biological distribution monitoring via spectroscopy.

C. Chemical property: high stability, cheap and convenient synthesis, solubility in water, and participation in the body kinetic cycle without the need to release intermediary such as liposomes and emulsions.

D. Biological property: low toxicity, rapid clearance from vascular system, selective absorption in tissue, 
and penetration into micron-size cellular targets [1, $38,45,50,52,77,80,83,122]$.

Some photosensitizers such as 5-aminolevulinic acid (Levulan), methyl aminolevulinate (Metvix), hexyl 5-aminolevulinate (Hexvix), and porfimer sodium (Photofrin) were approved by the FDA for clinical application of PDT [36].

A large number of new photosensitizers are synthesized via changes in structure of various compounds such as chlorines, bacteriochlorines, phthalocyanines, texarphions, and porphyrins.

\section{Deep tumors treatment by PDT}

Despite the advantages of photodynamic therapy, this method faces obstacles in the treatment of deep tumors using short wavelengths of light. Light with a range of visible and ultraviolet energy due to autofluorescence and scattering by biological systems cannot penetrate into deep tissues and limits treatment to tumors within a few millimeters of the tissue surface $[5,23,56,60,116,119]$.

The penetration depth increases as the wavelength of the incoming light increases and refers to the area that receives $37 \%$ of the incoming light. For example, the penetration depth of light with a wavelength of $693 \mathrm{~nm}$ in bladder tissue is approximately $40 \%$ greater than the penetration depth of light with a wavelength of $633 \mathrm{~nm}$ [101]. Meanwhile, the use of near-infrared (NIR) wavelengths in the biological windows I (650-950 nm) and II (1000$1350 \mathrm{~nm}$ ) makes it possible to treat tumors located at greater depths due to the reduction in autofluorescence and tissue dispersion in this area. So, there is a need for photosensitizers with absorption in this range of energy.

While the absorption wavelengths of most of photosensitizers are in the visible and ultraviolet regions, the amazing properties of some sensitizers and nanoparticles promise to use NIR light in the treatment of deep tumors.

\section{NIR photosensitizers}

Many advances in therapies have further limited barriers of NIR sensitizers such as low water solubility, low quantum yield, low stability in biological environments, low light detection sensitivity, and optical stability [60]. For the first time in Canada, the use of Photofrin with an absorption wavelength of $630 \mathrm{~nm}$ in the treatment of bladder tumors was an important event in photodynamic therapy.

Cyanine, squaraine derivatives, and BODIPY (borondipyrromethane) are the most important NIR adsorbent sensitizers used in clinical imaging trials. Porphyrins such as 3- (1'-butyloxy) ethyl-3-deacetylbacter-iopurpurin-18-N-butylimide methyl ester with significant absorption in the tumor and low optical toxicity in the skin was proposed as a functional agent in imaging and photodynamic therapy [87, 130]. Bromo-substituted BODIPY with high singlet oxygen quantum yield is suitable for the photodynamic treatment of deep-seated tumors [126]. Because of singlet oxygen production by porphyrin and phthalocyanine derivatives, meso-tetraarylporphyrins, core modified porphyrin dendrimers, and bacteriochlorines are recommended candidates for NIR-triggered photodynamic therapy [60]. One of the obstacles of PDT performance of these photosensitizers is the fluorescence quenching due to their aggregation in biological environments. Although some PSs with aggregationinduced emission (AIE) are introduced to overcome this limitation, their poor molar extinction coefficient and photobleaching feature made researchers interested in the application of nanoparticles in NIR-PDT $[20,41,117,120]$.

Some nanostructures based on gold, palladium, carbon, copper selenide, tungsten oxide, etc., are suggested in literatures as functional theranostic particles in NIRPDT and fluorescence imaging $[56,115]$. Among them, metallic gold nanostructures have been noted for their non-toxic and desirable optic nature (tunable localized surface plasmon resonances (LSPR)). To this end among the several gold nanoparticle morphologies, Au nano-echinus structures with high extinction coefficient of $\sim 10^{12} \mathrm{M}^{-1} \mathrm{~cm}^{-1}$ in the NIR region seem to exhibit excellent PDT efficiency in both biological windows I and II [104, 114].

\section{Biological targets in photodynamic therapy}

The type of photosensitizer and other parameters such as irradiation rate, time interval, and total dose of treatment are tunable for the selection of biological targets. Unlike radiotherapy, the main purpose of PDT is not to damage DNA, but instead of the prevention of cell proliferation, somatic death occurs [81]. In photodynamic therapy of some tumors such as prostate, photosensitizers also can act as tumor oxygen eliminators via vasculature targeting.

Tissue responses in PDT are very rapid and visible, even before the treatment is completed.

Photosensitizers are localized in the mitochondria, cytosol, cytosolic membranes, Golgi apparatus, plasma membrane, endoplasmic reticulum, mitochondria, lysosome, and endosome, and more selective tumor uptake is related to the differences in the physiology of normal and neoplastic tissues [62]. Tumors have more interior volume, permeable vascular system, lipoprotein receptors, and less extracellular $\mathrm{pH}$ and lymphatic drainage than normal tissues $[16,129]$. 


\section{Cell death pathways in photodynamic therapy}

During PDT, oxidative stress in endoplasmic reticulum and photo oxidative cell damage cause the two modes of cell death, necrosis and apoptosis (Fig. 2).

After the release of extracellular proteins outside the cell, the activation of immune cells, migration to the site of cellular damage, and phagocytosis of damaged cells are the next events leading to antigen presentation and $\mathrm{T}$ cell activation [9].

Necrosis and apoptosis are determined by the properties of photosensitizer, cell line, irradiance wavelength, power density of radiation, and the oxygen concentration [19]. Necrosis is occurred following the cytoplasm swelling, release of intracellular contents, and inflammation. In apoptosis cell shrinkage, plasma membrane blebbing and nuclear fragmentation caused cell death [58].

Generally, photosensitizers which localized in the mitochondria induce apoptosis, and those in the lysosome elicit the apoptosis or necrosis response. In plasma membrane apoptosis, necrosis and rescue responses are involved. Rescue responses are accompanied with changes of genes and expression of protein [71].

According to the reports of literatures, in general, lowdose PDT leads to apoptosis while high dose PDT is followed by more necrosis [19].

\section{Cellular signaling mechanism}

Proteins which are the most important factors in cell membrane signaling function are divided into transmembrane proteins (TM) and peripheral proteins. TM proteins with the ability to cross the membrane are included to receptors and transporters of the membrane. Ion channels are one of the membrane transporter categories with the role of neurotransmission and responsibility of cell signal transduction. Single-pass transmembrane receptors (SPTMRs) and G-protein-coupled receptors (GPCRs) also transmit the signals from the outside to the inside of the cells.

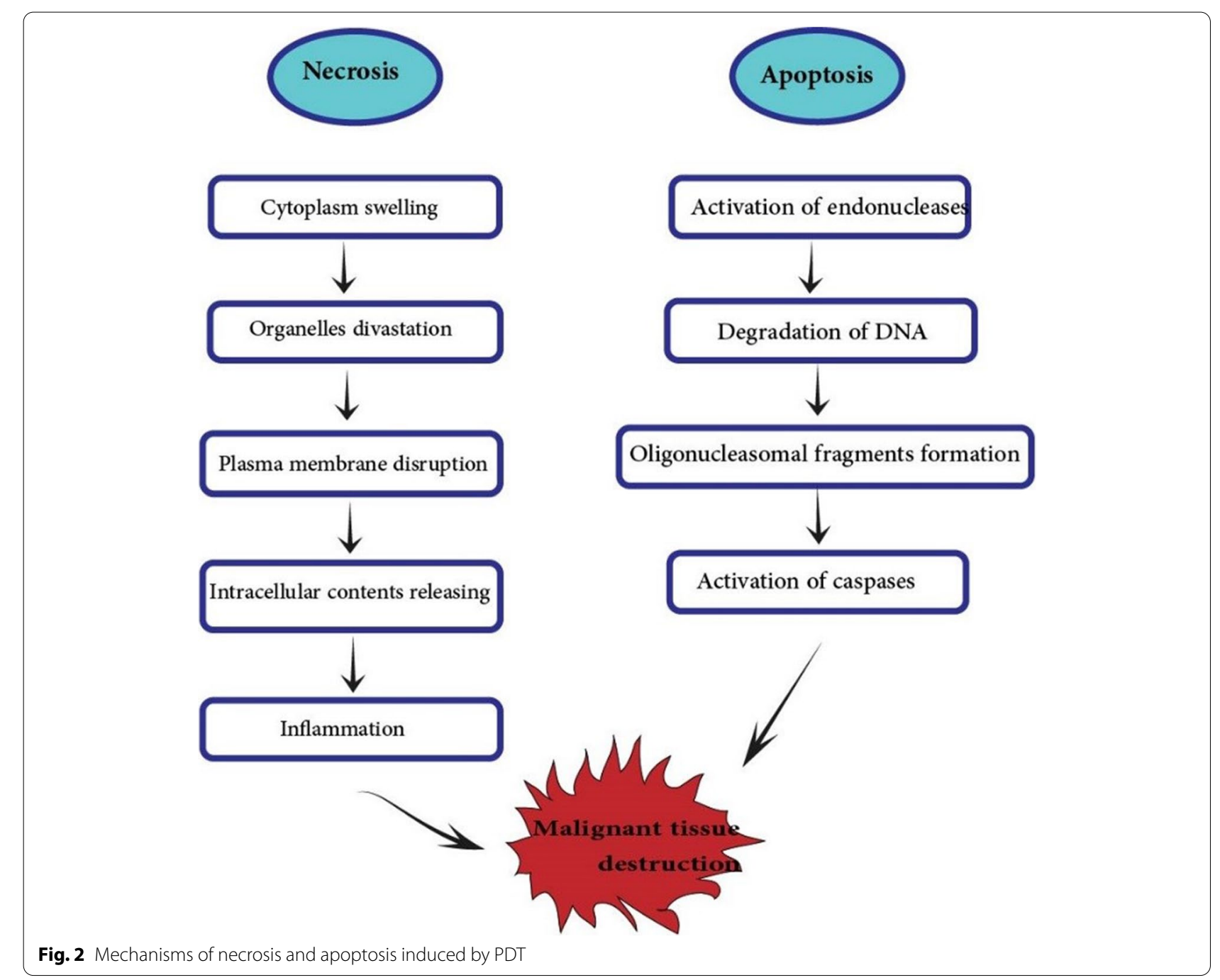




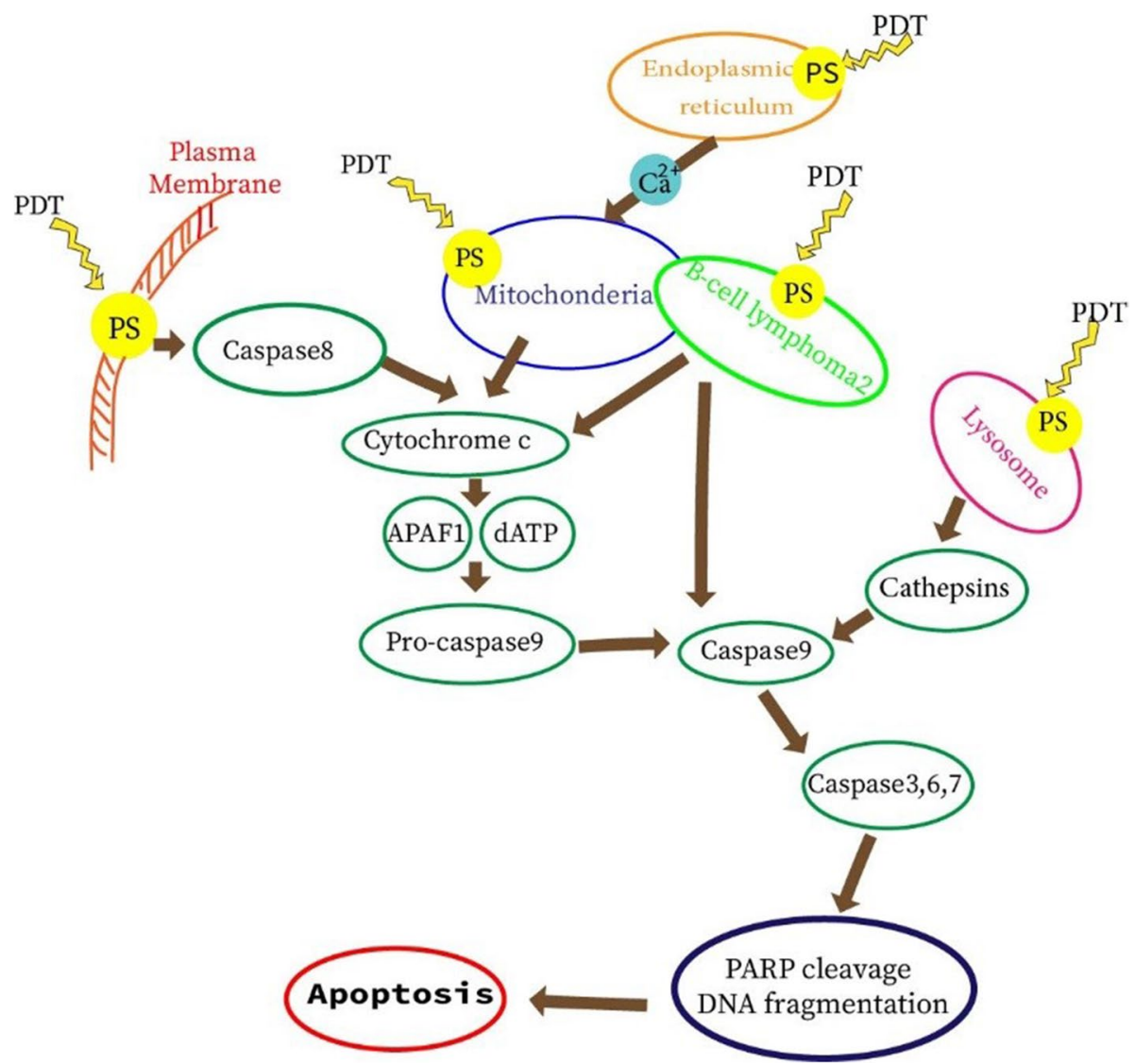

Fig. 3 Cellular signaling pathways based on photosensitizer (PS) localization and apoptosis induction upon PDT

Membrane-binding domains (MBDs) such as homology-1(C1) and homology-2 (C2), protein kinase $\mathrm{C}(\mathrm{PKC})$, EEA1 (FYVE), and pleckstrin homology (PH) have the essential role in recruiting the peripheral proteins to the membrane during the membrane signaling process. Lipid anchored proteins, transmembrane receptors, and lipidbinding proteins are a few samples of proteins associated in signaling events [21].

After PDT, increasing the free calcium level within the cells occurs via $\mathrm{Ca}^{2+}$ entrance through ion channels, $\mathrm{Ca}^{2+}$ secretion in the endoplasmic reticulum (ER) and mitochondria, and ion exchange mechanisms. It can be followed by cell death or in certain conditions by survival [19].

Apoptosis induced after PDT, by the mitochondrial localized photosensitizers such as benzoporphyrin derivative monoacid ring and silicone phthalocyanine Pc 4 , is following some signaling pathways. After illumination, cytochrome c releases into the cytosol, and because of the onset of permeability of the mitochondria and releasing of the $\mathrm{Ca}^{2+}$, rapid drop in the mitochondrial membrane potential is observed upon PDT. Caspase 3, procaspase 3, apoptosis-activating factor-1 (APAF-1), caspase 9 , and pro-caspase 9 are involved in the cleavage of DNA fragmentation factor (DFF) and poly (ADPribose) polymerase (PARP) enzyme (Fig. 3).

Some of signaling pathways belong to plasma membrane level. Phospholipase A2 (PLA2) and phospholipase $\mathrm{C}$ (PLC) enzymes are activated by PDT and participate in signal transduction. Releasing calcium from the internal stores also activate PLA2. In PDT of some cells such as T24 with hematoporphyrin derivatives, an increase in intracellular calcium leads to PLA2 activation and subsequently an increase in cAMP and prostaglandin E (PGE) with the important role in rescue response.

\section{Photodynamic therapy of solid tumors}

The efficacy of PDT in treatment of different solid tumors was investigated in several studies. In terms of clinical effectiveness, method standardization, result reproducibility, and publication number, there is a specific and degreed treatment mythology in skin, esophageal, lung, and head and neck cancers. Cholangiocarcinoma, 
mesothelioma, brain tumors, and prostate and bladder cancers are in the second level, and gynecology, breast, pancreas, and intraperitoneal cancers are characterized in the third level.

Surgery is the preferred modality with no recurrence in treatment of patients with skin cancers except in multiple lesions or specific location tumors which are assigned to PDT [69]. Furthermore, in patients with immune system defects or Gorlin syndrome, PDT is more recommended than surgery. In fact, the first experiments using PDT were against skin tumors. It was because of the ease of use and the possibility of monitoring the results and treatment progress. 5-Aminolevulinic acid or ALA (Levulan), methyl aminolevulinate (Metvixia) (MAL), and aminolevulinic acid hydrochloride (Ameluz) are the common used photosensitizers for PDT of actinic keratosis. Vegter et al. have reported that ALA-PDT was the most effective method in photodynamic therapy of mild to moderate actinic keratosis of face and scalp [113]. Desired response to treatment with this method was observed in $75-89 \%$ of patients [69]. A recent randomized trial comparing four frequently used methods in the treatment of actinic keratosis reports patients who were treated with fluorouracil had lower disease recurrence than those who received imiquimod, MAL-PDT, or ingenol mebutate [39].

5-Aminolevulinic acid or ALA (Levulan) and methyl aminolevulinate (Metvixia) are used in squamous cell carcinoma (SCC) PDT and have more clearance rate than cryotherapy and 5-fluoracil (5-FU) [129].

Jansen et al. in a 5-year randomized control trial found more treatment efficacy of basal cell carcinoma (BCC) in $5 \%$ imiquimod cream compared to both MAL-PDT and 5-FU [40]. In other research, BF-200 ALA-PDT of BCC was highly effective compared to MAL-PDT [73].

For the first time in 1983, PDT was used in the treatment of esophagus cancer. The role of PDT in dysphagia relief and improvement of quality of life is investigated in literatures [33, 61, 64, 68]. In Minamide et al.s study, talaporfin sodium-PDT divulged better outcomes than porfimer sodium-PDT for local failure after chemoradiotherapy or radiotherapy in esophageal cancer [67].

As in $80-85 \%$ of patients with lung cancer, the advanced stage of disease is diagnosed at the referral time, the surgery loses its justification. Neoadjuvant-PDT along with radiotherapy and chemotherapy is an option to improve quality of life in patients [69]. Chemo-photodynamic therapy was suggested by Zhang and his coworkers in treating the primary lung cancer $[28,133]$. Shafirstein et al. reviewed the PDT of nonsmall cell lung cancer (NSCLC). They summarized locally and peripheral tumors, pleural disease and margin control in palliative indications and early stage, and superficial and centrally located endobronchial NSCLC tumors in definitive cases [102]. The pleural membrane of the lung is affected by malignant pleural mesothelioma tumor. In recent years, local control improvement and increasing survival in cooperating PDT and other modalities such as proton therapy suggest encouraging outcomes $[69,96,103]$.

In head and neck cancers in addition to surgery, radiotherapy, and chemotherapy, PDT is a good candidate in early-stage diseases, neoadjuvant, intraoperative, and palliative therapy, or in cases of recurrence after treatment [69]. For example, the most important modality in treatment of early-stage oral cavity cancer is surgery, and PDT is an adjuvant treatment for involved margins [66]. Photodynamic therapy with Photofrin was concluded by Hosokawa et al. as useful for treating head and neck carcinoma [35].

Despite insufficient access to photosensitizers with the ability to accumulate in brain tumors as well as light source with appropriate wavelength matched with absorption wavelength of PS, the use of PDT in eliminating the tumor residues and treatment of recurrence cases has been proposed [69]. Intratumoral injection of PSs was suggested by Noske et al. to overcome the bloodbrain barrier in PDT of brain tumors, and pre-resection of tumor has an important role to maximize treatment outcome $[42,76]$.

In single-arm clinical trials, the result of a meta-analysis study confirms that PDT in patients with prostate cancer has short interval between PS administration and illumination, no skin photosensitization, and insignificant impact on erectile and urinary functions [69, 118]. Vascular targeted photodynamic therapy (VTP) was reported as a promising approach in the treatment of low-risk prostate cancer which is associated with increased quality of life [47].

Surgery in early-stage cholangiocarcinoma showed a prolonged survival time in $20-30 \%$ patients, and accompanying PDT in the treatment of extrahepatic biliary ducts tumors and nonresectable cholangiocarcinoma leads to more quality of life $[65,85]$. Combination of Foscan-PDT with stenting for cholangiocarcinoma reduced the side effects in Kniebühler et al.'s study [48]. The increase in survival created by chemo-photodynamic prompted Gonzalez-Carmona et al. to recommend it in treatment of advanced cholangiocarcinoma [31].

Since the 1980s, the use of PDT in bladder cancer was introduced in carcinoma in situ (CIS) and superficial transitional cell cancer (TCC). Nseyo et al., in a retrospective study, assessed PDT as an effective and safe treatment in 58 patients with resistant TCC and CIS [69, 79]. PDT also represented a less invasive and safe treatment for patients with superficial bladder cancer [13]. 


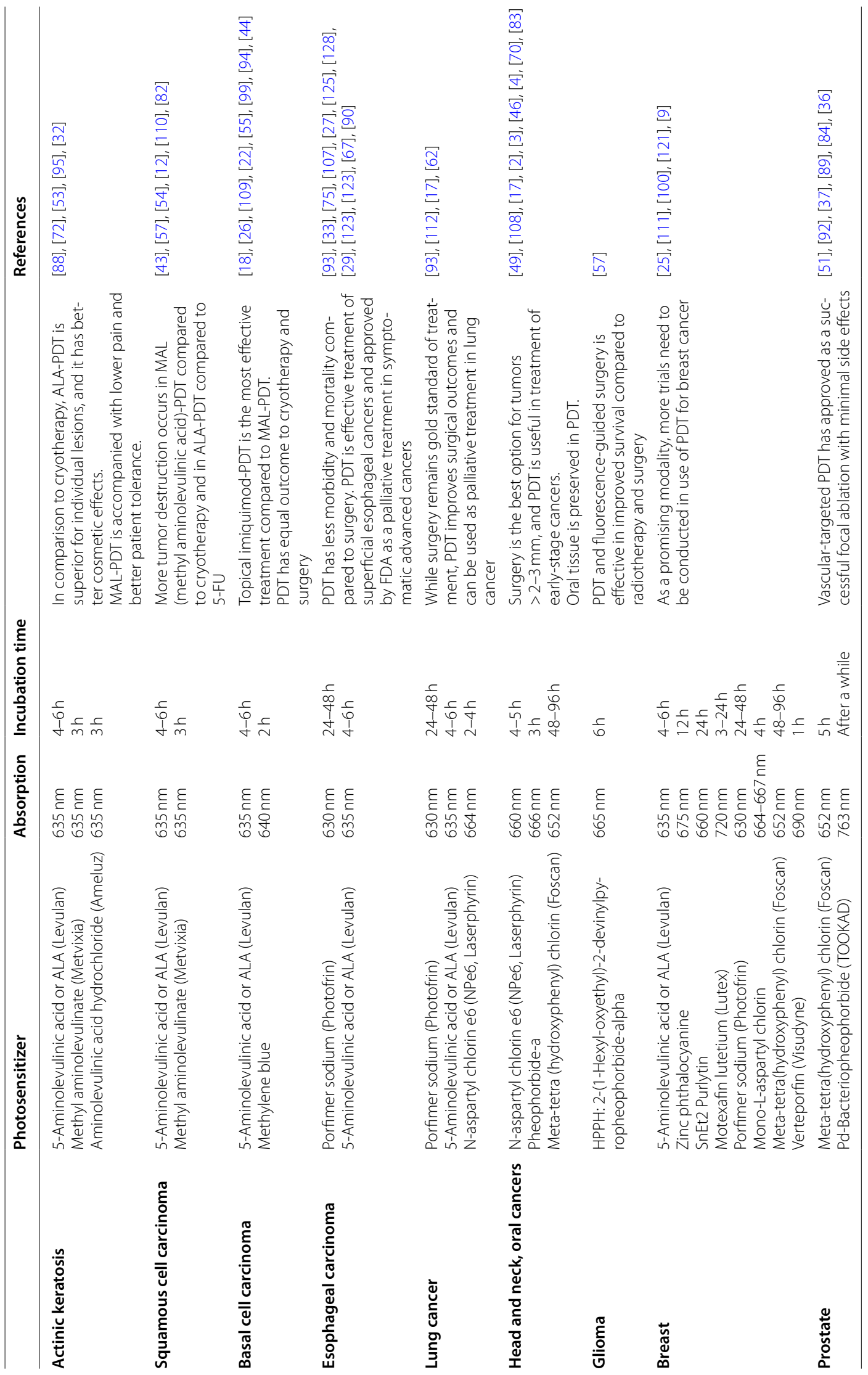


High-intensity focused ultrasound (HIFU) and radiofrequency ablation (RFA) are mentioned as two competitors of PDT of breast cancer by Banerjee et al. HIFU possesses the higher ratio of $\mathrm{CD} 4^{+}$to $\mathrm{CD} 8^{+} \mathrm{T}$ cell and maybe lower sustained adoptive immune response compare to PDT [9]. In recent years, PDT has remained as an area of interest in palliative treatments and limitation of drug resistance [7]. In this way, outcomes of PDT effectiveness on different tumors are provided in Table 2.

\section{Advantages of photodynamic therapy}

PDT is cheaper than common radiotherapy and surgery and reduces the post-treatment care time from a few weeks to a few hours. In this modality, irradiation is limited to the treatment region, so there is no photosensitizer activation in obscene of light and there is no cell destruction.

As a noninvasive method, it is a repeatable treatment in the same place. Induction of systemic anti-tumor immunity of PDT is used in the design of antitumor vaccines [30].

Due to the different amount of photosensitizer uptake in normal and neoplastic tissue, fluorescence emission of photosensitizer can be recorded as a noninvasive tumor marker in point monitoring and fluorescenceguided surgery [34].

PDT is generally fitted to superficial lesions; then, it is less efficient in the treatment of large and metastatic tumors. Anyway, with the help of reasonable highpower LEDs and upon excitation by the light source with long wavelength (NIR), the penetration depth increases [104].

\section{PDT side effects}

Pain, erythema, edema, and pustular skin disorder are the most common side effects of PDT along with rare side effects such as urticaria, contact dermatitis, or erosive pustular dermatosis of the scalp (EPDS). In some patients with skin cancer susceptibility, for example in cases with immunosuppression, non-melanoma skin cancer history, or photodamaged skin, the occurrence of basal cell carcinoma (BCC), squamous cell carcinoma (SCC), and melanoma were reported after PDT as consequences of immunosuppression, mutagenesis, and isotopic response [15].

Lehmann summarized the side effects of PDT as follows: pain $92 \%$, erythema/edema $89 \%$, flaking/itching $80 \%$, pustulation $6 \%$, erosion $1.2 \%$, hyper-hypopigmentation $1.0 \%$, and infections (bacterial/viral) $0.3 \%$ [86]. To minimize the cutaneous photosensitivity, rapid
Table 3 Photosensitivity of some photosensitizers

\begin{tabular}{ll}
\hline Photosensitizer & Skin photosensitivity \\
\hline 5-Aminolevulinic acid or ALA (Levulan) & 1-2 days \\
Methylene blue & 1-2 days \\
Porfimer sodium (Photofrin) & $3-8$ weeks \\
Verteporfin (Visudyne) & 1-5 days \\
HPPH: 2-(1-Hexyl-oxyethyl)-2-devinylpyropheo- & 6-8 weeks \\
phorbide-alpha & \\
N-aspartyl chlorin e6 (NPe6, Laserphyrin) & 1-2 weeks \\
Meta-tetra(hydroxyphenyl) chlorin (Foscan) & 3-6 weeks \\
\hline
\end{tabular}

accumulation in the target tissue and high clearance rate of photosensitizer is desirable (Table 3) [45].

\section{Conclusions}

The clinical use of PDT in therapy dates back to about 40 years ago, but the progress of science in this method has been ahead of the progress of its clinical applications. The effectiveness of PDT in cutaneous malignancies as a promising treatment modality and in some cases such as lung cancer as an adjuvant and palliative method has been proven in lots of literatures.

Although designing methods to overcome constraints such as photosensitivity, poor light penetration, low tumor selectivity, and systemic toxicity seems to be effective in PDT efficiency, more randomized clinical trials are needed to more expanded applications.

Mechanisms of subcellular and tumor localization of photosensitizing agents, as well as of molecular, cellular, and tumor responses associated with photodynamic therapy in conjunction with the technical issues regarding light dosimetry, are really of great importance. Importantly, besides the PDT in cancer treatment, we strongly recommend the role of miRNAs [8] and also stem cell therapy particularly CAR-T cell therapy $[6,98]$.

In general, it can be said that PDT can have a promising future as a cancer treatment for early diseases or as a synergistic therapy in multimodal oncology.

\section{Abbreviations \\ PDT: Photodynamic therapy; PS: Photosensitizer; TPPS: Tetraphenylporphine sulfonate; Pc: Phthalocyanine; AIPCS: Aluminum phthalocyanine sulfonates; mTHPC: Meta hydroxyl-phenyl; MBDs: Membrane-binding domains; PKC: Protein kinase C; PH: Pleckstrin homology; ER: Endoplasmic reticulum; APAF-1: Apoptosis-activating factor-1; DFF: DNA fragmentation factor; PLA2: Phospho- lipase A2; PLC: Phospholipase C; PGE: Prostaglandin E; CIS: Carcinoma in situ.}

\section{Acknowledgements}

The authors express their gratitude and appreciation to all persons who contributed in this manuscript. 


\section{Authors' contributions}

NS accomplished the data processing, investigated the informatics database, and also wrote the article. AAS edited and revised the manuscript comprehensively. All authors revised the article completely and confirmed the final edited version of the paper.

\section{Funding}

No funding.

\section{Availability of data and materials}

The datasets used and/or analysed during the current study are available from the corresponding author on reasonable request.

\section{Declarations}

Ethics approval and consent to participate

Not applicable. It is a review article.

\section{Consent for publication}

Not applicable.

\section{Competing interests}

The authors declare no competing interests.

\section{Author details}

${ }^{1}$ Department of Basic Medical Sciences, Neyshabur University of Medical Sciences, Neyshabur, Iran. ${ }^{2}$ Healthy Ageing Research Center, Neyshabur University of Medical Sciences, Neyshabur, Iran. ${ }^{3}$ Clinical Research Development Unit of Poursina Hospital, Guilan University of Medical Sciences, Rasht, Iran.

\section{Received: 25 May 2021 Accepted: 24 September 2021}

Published online: 15 November 2021

\section{References}

1. Agostinis P, Berg K, Cengel KA, Foster TH, Girotti AW, Gollnick SO, et al. Photodynamic therapy of cancer: an update. CA Cancer J Clin. 2011;61(4):250-81. https://doi.org/10.3322/caac.20114.

2. Ahn M-Y, Kwon S-M, Kim Y-C, Ahn S-G, Yoon J-H. Pheophorbide a-mediated photodynamic therapy induces apoptotic cell death in murine oral squamous cell carcinoma in vitro and in vivo. Oncol Rep. 2012;27(6):1772-8. https://doi.org/10.3892/or.2012.1748.

3. Ahn MY, Yoon H-E, Kwon S-M, Lee J, Min S-K, Kim Y-C, et al. Synthesized Pheophorbide a-mediated photodynamic therapy induced apoptosis and autophagy in human oral squamous carcinoma cells. J Oral Pathol Med. 2013;42(1):17-25. https://doi.org/10.1111/j.1600-0714.2012. 01187.X.

4. Ahn M-Y, Yoon H-E, Moon S-Y, Kim Y-C, Yoon J-H. Intratumoral photodynamic therapy with newly synthesized pheophorbide a in murine oral cancer. Oncol Res. 2017;25(2):295-304. https://doi.org/10.3727/09650 4016X14732527645922.

5. Ai X, Mu J, Xing B. Recent advances of light-mediated theranostics. Theranostics. 2016;6(13):2439-57. https://doi.org/10.7150/thno.16088.

6. Akbar Samadani A, Keymoradzdeh A, Shams S, Soleymanpour A, Elham Norollahi S, Vahidi S, et al. Mechanisms of cancer stem cell therapy. Clin Chim Acta. 2020;510:581-92. https://doi.org/10.1016/j. cca.2020.08.016.

7. Aniogo EC, Plackal Adimuriyil George B, Abrahamse $\mathrm{H}$. The role of photodynamic therapy on multidrug resistant breast cancer. Cancer Cell Int. 2019:19(1):91. https://doi.org/10.1186/s12935-019-0815-0.

8. Babaei K, Shams S, Keymoradzadeh A, Vahidi S, Hamami P, Khaksar R, et al. An insight of microRNAs performance in carcinogenesis and tumorigenesis; an overview of cancer therapy. Life Sci. 2020;240:117077. https://doi.org/10.1016/j.lfs.2019.117077.

9. Banerjee SM, MacRobert AJ, Mosse CA, Periera B, Bown SG, Keshtgar MRS. Photodynamic therapy: inception to application in breast cancer. Breast. 2017;31:105-13. https://doi.org/10.1016/j.breast.2016.09.016.

10. Baptista MS, Cadet J, Mascio PD, Ghogare AA, Greer A, Hamblin MR, et al. Type I and type II photosensitized oxidation reactions: guidelines and mechanistic pathways. Photochem Photobiol. 2017;93(4):912-9. https://doi.org/10.1111/php.12716.

11. Baskaran R, Lee J, Yang S-G. Clinical development of photodynamic agents and therapeutic applications. Biomater Res. 2018;22(1):25. https://doi.org/10.1186/s40824-018-0140-z.

12. Bath-Hextall FJ, Matin RN, Wilkinson D, Leonardi-Bee J. Interventions for cutaneous Bowen's disease. Cochrane Database Syst Rev. 2013;(6). https:// doi.org/10.1002/14651858.CD007281.pub2 [Accessed 20 Oct 2020].

13. Berger AP, Steiner H, Stenzl A, Akkad T, Bartsch G, Holtl L. Photodynamic therapy with intravesical instillation of 5-aminolevulinic acid for patients with recurrent superficial bladder cancer: a single-center study. Urology. 2003;61(2):338-41. https://doi.org/10.1016/S0090-4295(02) 02123-4.

14. Bonnett R, Martínez G. Photobleaching of sensitisers used in photodynamic therapy. Tetrahedron. 2001;57(47):9513-47. https://doi.org/10. 1016/S0040-4020(01)00952-8.

15. Borgia F, Giuffrida R, Caradonna E, Vaccaro M, Guarneri F, Cannavò SP. Early and late onset side effects of photodynamic therapy. Biomedicines. 2018;6(1). https://doi.org/10.3390/biomedicines6010012.

16. Brown SB, Brown EA, Walker I. The present and future role of photodynamic therapy in cancer treatment. Lancet Oncol. 2004;5(8):497-508. https://doi.org/10.1016/S1470-2045(04)01529-3.

17. Busch T, Cengel KA, Finlay J. Pheophorbide a as a photosensitizer in photodynamic therapy: in vivo considerations. Cancer Biol Ther. 2009;8(6):540-2. https://doi.org/10.4161/cbt.8.6.8067.

18. Batlle ADC. Porphyrins, porphyrias, cancer and photodynamic therapy - a model for carcinogenesis. J Photochem Photobiol B. 1993;20(1):522. https://doi.org/10.1016/1011-1344(93)80127-U.

19. Castano AP, Demidova TN, Hamblin MR. Mechanisms in photodynamic therapy: part two_-cellular signaling, cell metabolism and modes of cell death. Photodiagnosis Photodyn Ther. 2005;2(1):1-23. https://doi. org/10.1016/S1572-1000(05)00030-X.

20. Chen Q, Chen J, Yang Z, Zhang L, Dong Z, Liu Z. NIR-II light activated photodynamic therapy with protein-capped gold nanoclusters. Nano Res. 2018;11(10):5657-69. https://doi.org/10.1007/s12274-017-1917-4.

21. Cheng X, Smith JC. Biological membrane organization and cellular signaling. Chem Rev. 2019. https://doi.org/10.1021/acs.chemrev.8b004 39 [Accessed 30 Nov 2020].

22. Cosgarea R, Susan M, Crisan M, Senila S. Photodynamic therapy using topical 5-aminolaevulinic acid vs. surgery for basal cell carcinoma. J Eur Acad Dermatol Venereol. 2013;27(8):980-4. https://doi.org/10.1111/j. 1468-3083.2012.04619x.

23. Cui S, Yin D, Chen Y, Di Y, Chen H, Ma Y, et al. In vivo targeted deeptissue photodynamic therapy based on near-infrared light triggered upconversion nanoconstruct. ACS Nano. 2013;7(1):676-88. https://doi. org/10.1021/nn304872n.

24. Ding H, Yu H, Dong Y, Tian R, Huang G, Boothman DA, et al. Photoactivation switch from type II to type I reactions by electron-rich micelles for improved photodynamic therapy of cancer cells under hypoxia. J Control Release. 2011;156(3):276-80. https://doi.org/10.1016/j.jconrel. 2011.08.019.

25. Dolmans DEJGJ, Fukumura D, Jain RK. Photodynamic therapy for cancer Nat Rev Cancer. 2003;3(5):380-7. https://doi.org/10.1038/nrc1071.

26. Dougherty TJ. An update on photodynamic therapy applications. J Clin Laser Med Surg. 2002;20(1):3-7. https://doi.org/10.1089/1044547027 53474931.

27. Dunn JM, Banks MR, Oukrif D, Mackenzie GD, Thorpe S, RodriguezJusto $M$, et al. Radiofrequency ablation is effective for the treatment of high-grade dysplasia in Barrett's esophagus after failed photodynamic therapy. Endoscopy. 2011;43(7):627-30. https://doi.org/10.1055/s-00301256443.

28. El-Hussein A, Manoto SL, Ombinda-Lemboumba S, Alrowaili ZA, Mthunzi-Kufa P. A review of chemotherapy and photodynamic therapy for lung cancer treatment. Anti-Cancer Agents Med Chem- Anti-Cancer Agents. 2021;21(2):149-61. https://doi.org/10.2174/187152062066620 0403144945.

29. Gao S, Zhang M, Zhu X, Qu Z, Shan T, Xie X, et al. Apoptotic effects of Photofrin-Diomed 630-PDT on SHEEC human esophageal squamous cancer cells. Int J Clin Exp Med. 2015;8(9):15098-107.

30. Garg AD, Nowis D, Golab J, Agostinis P. Photodynamic therapy: illuminating the road from cell death towards anti-tumour immunity. 
Apoptosis Int J Program Cell Death. 2010;15(9):1050-71. https://doi. org/10.1007/s10495-010-0479-7.

31. Gonzalez-Carmona MA, Bolch M, Jansen C, Vogt A, Sampels M, Mohr $\mathrm{RU}$, et al. Combined photodynamic therapy with systemic chemotherapy for unresectable cholangiocarcinoma. Aliment Pharmacol Ther. 2019;49(4):437-47. https://doi.org/10.1111/apt.15050.

32. Griffin LL, Lear JT. Photodynamic therapy and non-melanoma skin cancer. Cancers. 2016;8(10). https://doi.org/10.3390/cancers8100098.

33. Gross SA, Wolfsen HC. The role of photodynamic therapy in the esophagus. Gastrointest Endosc Clin. 2010;20(1):35-53. https://doi.org/10. 1016/j.giec.2009.07.008.

34. He J, Yang L, Yi W, Fan W, Wen Y, Miao X, et al. Combination of fluorescence-guided surgery with photodynamic therapy for the treatment of cancer. Mol Imaging. 2017;16:1536012117722911. https://doi.org/10. 1177/1536012117722911.

35. Hosokawa S, Takahashi G, Sugiyama K, Takebayashi S, Okamura J, Takizawa Y, et al. Porfimer sodium-mediated photodynamic therapy in patients with head and neck squamous cell carcinoma. Photodiagnosis Photodyn Ther. 2020;29:101627. https://doi.org/10.1016/j.pdpdt.2019. 101627.

36. How promising is phototherapy for cancer? n.d. | British Journal of Cancer. [Accessed 28 Oct 2020]. https://www.nature.com/articles/ s41416-020-0926-3.

37. Huang Z, Chen Q, Trncic N, LaRue SM, Brun P-H, Wilson BC, et al. Effects of Pd-bacteriopheophorbide (TOOKAD)-mediated photodynamic therapy on canine prostate pretreated with ionizing radiation. Radiat Res. 2004;161(6):723-31.

38. Hudson D, Hudson D, Wininger J, Richardson B. Penetration of laser light at 808 and $980 \mathrm{~nm}$ in bovine tissue samples. Photomed Laser Surg. 2013;31. https://doi.org/10.1089/pho.2012.3284.

39. Jansen MHE, Kessels JPHM, Nelemans PJ, Kouloubis N, Arits AHMM, van Pelt HPA, et al. Randomized trial of four treatment approaches for actinic keratosis. N Engl J Med. 2019;380(10):935-46. https://doi.org/10. 1056/NEJMoa1811850.

40. Jansen MHE, Mosterd $K$, Arits AHMM, Roozeboom MH, Sommer A, Essers $B A B$, et al. Five-year results of a randomized controlled trial comparing effectiveness of photodynamic therapy, topical imiquimod, and topical 5 -fluorouracil in patients with superficial basal cell carcinoma. J Invest Dermatol. 2018;138(3):527-33. https://doi.org/10. 1016/j.jid.2017.09.033.

41. Jin L, Shen S, Huang Y, Li D, Yang X. Corn-like Au/Ag nanorod-mediated NIR-II photothermal/photodynamic therapy potentiates immune checkpoint antibody efficacy by reprogramming the cold tumor microenvironment. Biomaterials. 2021;268:120582. https://doi.org/10.1016/j. biomaterials.2020.120582.

42. Kaneko S, Fujimoto S, Yamaguchi H, Yamauchi T, Yoshimoto T, Tokuda K. Photodynamic therapy of malignant gliomas. Intracranial Gliomas Part III Innov Treat Modalities. 2018;32:1-13. https://doi.org/10.1159/ 000469675.

43. Katsumi TA, Aizawa K, Kuroiwa Y, Saito K, Kurata Y, Li Y, et al. Photodynamic therapy with a diode laser for implanted fibrosarcoma in mice employing mono-L-aspartyl chlorin E6. Photochem Photobiol. 1996;64(4):671-5. https://doi.org/10.1111/j.1751-1097.1996.tb03122.x.

44. Kessels JPHM, Kreukels $H$, Nelemans PJ, Roozeboom MH, van Pelt $H$, Mosterd K, et al. Treatment of superficial basal cell carcinoma by topical photodynamic therapy with fractionated 5-aminolaevulinic acid 20\% vs. two-stage topical methyl aminolaevulinate: results of a randomized controlled trial. Br J Dermatol. 2018;178(5):1056-63. https://doi.org/10. 1111/bjd.15967.

45. Kim MM, Darafsheh A. Light sources and dosimetry techniques for photodynamic therapy. Photochem Photobiol. 2020;96(2):280-94. https:// doi.org/10.1111/php.13219.

46. Kim S-A, Lee MR, Yoon J-H, Ahn S-G. HOXC6 regulates the antitumor effects of pheophorbide a-based photodynamic therapy in multidrugresistant oral cancer cells. Int J Oncol. 2016;49(6):2421-30. https://doi. org/10.3892/ijo.2016.3766.

47. Kleinclauss F, Frontczak A, Balssa L, Lebdai S, Azzouzi R. Vascular targeted photodynamic therapy in low-risk prostate cancer. A literature review. Prog Urol. 2019;29(8-9):393-401. https://doi.org/10.1016/j.purol. 2019.05.004.
48. Kniebühler G, Pongratz T, Betz CS, Göke B, Sroka R, Stepp H, et al. Photodynamic therapy for cholangiocarcinoma using low dose mTHPC (Foscan ${ }^{\circledR}$ ). Photodiagnosis Photodyn Ther. 2013;10(3):220-8. https://doi. org/10.1016/j.pdpdt.2012.12.005.

49. Kobayashi W, Liu Q, Nakagawa H, Sakaki H, Teh B, Matsumiya T, et al. Photodynamic therapy with mono-L-aspartyl chlorin e6 can cause necrosis of squamous cell carcinoma of tongue: experimental study on an animal model of nude mouse. Oral Oncol. 2006;42(1):46-50. https:// doi.org/10.1016/j.oraloncology.2005.05.009.

50. Kou J, Dou D, Yang L. Porphyrin photosensitizers in photodynamic therapy and its applications. Oncotarget. 2017;8(46):81591-603. https:// doi.org/10.18632/oncotarget.20189.

51. Koudinova NV, Pinthus JH, Brandis A, Brenner O, Bendel P, Ramon $J$, et al. Photodynamic therapy with Pd-Bacteriopheophorbide (TOOKAD): successful in vivo treatment of human prostatic small cell carcinoma xenografts. Int J Cancer. 2003;104(6):782-9. https://doi.org/ 10.1002/ijc.11002.

52. Kwiatkowski S, Knap B, Przystupski D, Saczko J, Kędzierska E, Knap-Czop $\mathrm{K}$, et al. Photodynamic therapy - mechanisms, photosensitizers and combinations. Biomed Pharmacother. 2018;106:1098-107. https://doi. org/10.1016/j.biopha.2018.07.049.

53. Lee JW, Lee HI, Kim MN, Kim BJ, Chun Y-J, Kim D. Topical photodynamic therapy with methyl aminolevulinate may be an alternative therapeutic option for the recalcitrant Malassezia folliculitis. Int J Dermatol. 2011;50(4):488-90. https://doi.org/10.1111/j.1365-4632.2009.04377.x.

54. Lee LS, Thong PSP, Olivo M, Chin WWL, Ramaswamy B, Kho KW, et al. Chlorin e6-polyvinylpyrrolidone mediated photodynamic therapy--A potential bladder sparing option for high risk non-muscle invasive bladder cancer. Photodiagnosis Photodyn Ther. 2010;7(4):213-20. https:// doi.org/10.1016/j.pdpdt.2010.08.005.

55. Lippert J, Šmucler R, Vlk M. Fractional carbon dioxide laser improves nodular basal cell carcinoma treatment with photodynamic therapy with methyl 5-aminolevulinate. Dermatol Surg. 2013;39(8):1202-8. https://doi.org/10.1111/dsu.12242.

56. Liu B, Li C, Cheng Z, Hou Z, Huang S, Lin J. Functional nanomaterials for near-infrared-triggered cancer therapy. Biomater Sci. 2016;4(6):890-909. https://doi.org/10.1039/C6BM00076B.

57. Lobel J, MacDonald IJ, Ciesielski MJ, Barone T, Potter WR, Pollina J, et al. 2-[1-hexyloxyethyl]-2-devinyl pyropheophorbide-a (HPPH) in a nude rat glioma model: implications for photodynamic therapy. Lasers Surg Med. 2001;29(5):397-405. https://doi.org/10.1002/lsm.10001.

58. Lowe SW, Lin AW. Apoptosis in cancer. Carcinogenesis. 2000;21(3):48595. https://doi.org/10.1093/carcin/21.3.485.

59. Luo L, Sun W, Feng Y, Qin R, Zhang J, Ding D, et al. Conjugation of a scintillator complex and gold nanorods for dual-modal image-guided photothermal and X-ray-induced photodynamic therapy of tumors. ACS Appl Mater Interf. 2020;12(11):12591-9. https://doi.org/10.1021/ acsami.0c01189.

60. Luo S, Zhang E, Su Y, Cheng T, Shi C. A review of NIR dyes in cancer targeting and imaging. Biomaterials. 2011;32(29):7127-38. https://doi. org/10.1016/j.biomaterials.2011.06.024.

61. Maier A, Tomaselli F, Gebhard F, Rehak P, Smolle J, Smolle-Jüttner F. Palliation of advanced esophageal carcinoma by photodynamic therapy and irradiation. Ann Thorac Surg. 2000;69:1006-9. https://doi.org/10. 1016/S0003-4975(99)01440-X.

62. Mansoori B, Mohammadi A, Amin Doustvandi M, Mohammadnejad F, Kamari F, Gjerstorff MF, et al. Photodynamic therapy for cancer: role of natural products. Photodiagnosis Photodyn Ther. 2019;26:395-404. https://doi.org/10.1016/j.pdpdt.2019.04.033.

63. Marcus SL. Photodynamic therapy of human cancer: clinical status, potential, and needs. In: Future Dir Appl Photodyn Ther [Internet]. Vol. 10306. [place unknown]: International Society for Optics and Photonics 1990; [Accessed 202026 Oct]; p. 1030603. https://doi.org/10.1117/12. 2283665

64. McCaughan JS, Ellison EC, Guy JT, Hicks WJ, Jones JJ, Laufman LR, et al. Photodynamic therapy for esophageal malignancy: a prospective twelve-year study. Ann Thorac Surg. 1996;62(4):1005-10. https://doi. org/10.1016/0003-4975(96)00563-2.

65. McCaughan JS, Mertens BF, Cho C, Barabash RD, Payton HW. Photodynamic therapy to treat tumors of the extrahepatic biliary ducts: a case 
report. Arch Surg. 1991;126(1):111-3. https://doi.org/10.1001/archsurg. 1991.01410250119022.

66. Meulemans J, Delaere P, Vander Poorten V. Photodynamic therapy in head and neck cancer: indications, outcomes, and future prospects. Curr Opin Otolaryngol Head Neck Surg. 2019;27(2):136-41. https://doi. org/10.1097/MOO.0000000000000521.

67. Minamide T, Yoda Y, Hori K, Shinmura K, Oono Y, Ikematsu H, et al. Advantages of salvage photodynamic therapy using talaporfin sodium for local failure after chemoradiotherapy or radiotherapy for esophageal cancer. Surg Endosc. 2020;34(2):899-906. https://doi.org/10.1007/ s00464-019-06846-3.

68. Moghissi K. Where does photodynamic therapy fit in the esophageal cancer treatment jigsaw puzzle? J Natl Compr Canc Netw. 2012;10(Suppl_2):S-52-5. https://doi.org/10.6004/jnccn.2012.0176.

69. Moghissi K, Dixon K, Gibbins S. A surgical view of photodynamic therapy in oncology: a review. Surg J. 2015;1(1):e1-e15. https://doi.org/ 10.1055/s-0035-1565246.

70. Moon S, Kim DK, Kim J. Apoptosis-related microRNA-145-5p enhances the effects of pheophorbide a-based photodynamic therapy in oral cancer. Oncotarget. 2017;8(21):35184-92. https://doi.org/10.18632/ oncotarget.17059.

71. Moor ACE. Signaling pathways in cell death and survival after photodynamic therapy. J Photochem Photobiol B. 2000;57(1):1-13. https://doi. org/10.1016/S1011-1344(00)00065-8.

72. Morton CA. Methyl aminolevulinate: actinic keratoses and Bowen's disease. Dermatol Clin. 2007;25(1):81-7. https://doi.org/10.1016/j.det. 2006.09.009.

73. Morton CA, Dominicus R, Radny P, Dirschka T, Hauschild A, Reinhold U, et al. A randomized, multinational, noninferiority, phase III trial to evaluate the safety and efficacy of BF-200 aminolaevulinic acid gel vs. methyl aminolaevulinate cream in the treatment of nonaggressive basal cell carcinoma with photodynamic therapy. Br J Dermatol. 2018;179(2):30919. https://doi.org/10.1111/bjd.16441.

74. Nardone V, Vinciguerra C, Tini P, Rocchi R, Pirtoli L. Persistent hiccup after chemo-radiotherapy in nasopharyngeal cancer: an atypical side effect? Acta Neurol Belg. 2017;117(1):381-3. https://doi.org/10.1007/ s13760-016-0659-5.

75. Nava HR, Allamaneni SS, Dougherty TJ, Cooper MT, Tan W, Wilding G, et al. Photodynamic therapy (PDT) using HPPH for the treatment of precancerous lesions associated with Barrett's esophagus. Lasers Surg Med. 2011;43(7):705-12. https://doi.org/10.1002/lsm.21112.

76. Noske DP, Wolbers JG, Sterenborg HJCM. Photodynamic therapy of malignant glioma: a review of literature. Clin Neurol Neurosurg. 1991;93(4):293-307. https://doi.org/10.1016/0303-8467(91)90094-6.

77. Nowak-Stepniowska A, Pergoł P, Padzik-Graczyk A. Photodynamic method of cancer diagnosis and therapy--mechanisms and applications. Postepy Biochem. 2013;59(1):53-63.

78. Nowis D, Makowski M, Stokłosa T, Legat M, Issat T, Gołab J. Direct tumor damage mechanisms of photodynamic therapy. Acta Biochim Pol. 2005;52(2):339-52.

79. Nseyo UO, DeHAVEN J, Dougherty TJ, Potter WR, Merrill DL, Lundahl SL, et al. Photodynamic therapy (PDT) in the treatment of patients with resistant superficial bladder cancer: a long term experience. J Clin Laser Med Surg. 1998;16(1):61-8. https://doi.org/10.1089/clm.1998.16.61.

80. Nyman ES, Hynninen PH. Research advances in the use of tetrapyrrolic photosensitizers for photodynamic therapy. J Photochem Photobiol B. 2004;73(1-2):1-28. https://doi.org/10.1016/j.jphotobiol.2003.10.002.

81. Ochsner M. Photophysical and photobiological processes in the photodynamic therapy of tumours. J Photochem Photobiol B. 1997;39(1):118. https://doi.org/10.1016/s1011-1344(96)07428-3.

82. O'Connell KA, Okhovat J-P, Zeitouni NC. Photodynamic therapy for Bowen's Disease (squamous cell carcinoma in situ) current review and update. Photodiagnosis Photodyn Ther. 2018;24:109-14. https://doi. org/10.1016/j.pdpdt.2018.09.009.

83. Ohtani K, Usuda J, Ogawa E, Maehara S, Imai K, Kudo Y, et al. Skin fluorescence following photodynamic therapy with NPe6 photosensitizer. Photodiagnosis Photodyn Ther. 2017;20:210-4. https://doi.org/10. 1016/j.pdpdt.2017.10.001

84. Ormond AB, Freeman HS. Dye sensitizers for photodynamic therapy. Materials. 2013;6(3):817-40. https://doi.org/10.3390/ma6030817.
85. Ortner M-AEJ, Liebetruth J, Schreiber S, Hanft M, Wruck U, Fusco V, et al. Photodynamic therapy of nonresectable cholangiocarcinoma. Gastroenterology. 1998;114(3):536-42. https://doi.org/10.1016/S00165085(98)70537-2.

86. $\mathrm{P}$ L. Side effects of topical photodynamic therapy. Hautarzt Z Dermatol Venerol Verwandte Geb. 2007;58(7):597-603. https://doi.org/10.1007/ s00105-007-1363-4.

87. Patel N, Pera P, Joshi P, Dukh M, Tabaczynski WA, Siters KE, et al. Highly effective dual-function near-infrared (NIR) photosensitizer for fluorescence imaging and photodynamic therapy (PDT) of cancer. J Med Chem. 2016;59(21):9774-87. https://doi.org/10.1021/acs.jmedchem. 6 b00890.

88. Peng Q, Berg K, Moan J, Kongshaug M, Nesland JM. 5-Aminolevulinic acid-based photodynamic therapy: principles and experimental research. Photochem Photobiol. 1997;65(2):235-51. https://doi.org/ 10.1111/j.1751-1097.1997.tb08549.x.

89. Petri A, Yova D, Alexandratou E, Kyriazi M, Rallis M. Comparative characterization of the cellular uptake and photodynamic efficiency of Foscan ${ }^{\circledR}$ and Fospeg in a human prostate cancer cell line. Photodiagnosis Photodyn Ther. 2012;9(4):344-54. https://doi.org/10.1016/j. pdpdt.2012.03.008.

90. Photodynamic therapy for gastrointestinal cancer - Yano - 2020 photochemistry and photobiology - Wiley Online Library. [Accessed 27 Oct 2020]. https://doi.org/10.1111/php.13206.

91. Plaetzer K, Krammer B, Berlanda J, Berr F, Kiesslich T. Photophysics and photochemistry of photodynamic therapy: fundamental aspects. Lasers Med Sci. 2009;24(2):259-68. https://doi.org/10.1007/ s10103-008-0539-1.

92. Plaks V, Koudinova N, Nevo U, Pinthus JH, Kanety H, Eshhar Z, et al. Photodynamic therapy of established prostatic adenocarcinoma with TOOKAD: a biphasic apparent diffusion coefficient change as potential early MRI response marker. Neoplasia. 2004;6(3):224-33. https:// doi.org/10.1593/neo.03352.

93. Pushpan SK, Venkatraman S, Anand VG, Sankar J, Parmeswaran D, Ganesan S, et al. Porphyrins in photodynamic therapy - a search for ideal photosensitizers. Curr Med Chem Anti-Cancer Agents. 2002;2(2):187-207. https://doi.org/10.2174/1568011023354137.

94. Qidwai A, Khan S, Md S, Fazil M, Baboota S, Narang JK, et al. Nanostructured lipid carrier in photodynamic therapy for the treatment of basal-cell carcinoma. Drug Deliv. 2016;23(4):1476-85. https://doi.org/ 10.3109/10717544.2016.1165310.

95. Reinhold U, Dirschka T, Ostendorf R, Aschoff R, Berking C, PhilippDormston WG, et al. A randomized, double-blind, phase III, multicentre study to evaluate the safety and efficacy of BF-200 ALA (Ameluz $\left({ }^{\circledR}\right)$ ) vs. placebo in the field-directed treatment of mild-tomoderate actinic keratosis with photodynamic therapy (PDT) when using the BF-RhodoLED $\left.{ }^{(}\right)$lamp. Br J Dermatol. 2016;175(4):696-705. https://doi.org/10.1111/bjd.14498.

96. Rice SR, Li YR, Busch TM, Kim MM, McNulty S, Dimofte A, et al. A novel prospective study assessing the combination of photodynamic therapy and proton radiation therapy: safety and outcomes when treating malignant pleural mesothelioma. Photochem Photobiol. 2019:95(1):411-8. https://doiorg/10.1111/php.13065.

97. Robertson CA, Evans DH, Abrahamse H. Photodynamic therapy (PDT): a short review on cellular mechanisms and cancer research applications for PDT. J Photochem Photobiol B. 2009;96(1):1-8. https://doi. org/10.1016/j.jphotobiol.2009.04.001.

98. Samadani AA, Keymoradzdeh A, Shams S, Soleymanpour A, RashidyPour A, Hashemian $\mathrm{H}$, et al. CART-cells profiling in carcinogenesis and tumorigenesis: an overview of CAR T-cells cancer therapy. Int Immunopharmacol. 2021;90:107201. https://doi.org/10.1016/j.intimp. 2020.107201

99. Samy NA, Salah MM, Ali MF, Sadek AM. Effect of methylene bluemediated photodynamic therapy for treatment of basal cell carcinoma. Lasers Med Sci. 2015;30(1):109-15. https://doi.org/10.1007/ s10103-014-1609-1.

100. Senge MO, Brandt JC. Temoporfin (Foscan ${ }^{\circledR}, 5,10,15,20$-tetra(mhydroxyphenyl)chlorin)--a second-generation photosensitizer. Photochem Photobiol. 2011;87(6):1240-96. https://doi.org/10.1111/j. 1751-1097.2011.00986.x. 
101. Shackley DC, Whitehurst C, Moore JV, George NJ, Betts CD, Clarke NW. Light penetration in bladder tissue: implications for the intravesical photodynamic therapy of bladder tumours. BJU Int. 2000;86(6):63843. https://doi.org/10.1046/j.1464-410x.2000.00872.x.

102. Shafirstein G, Battoo A, Harris K, Baumann H, Gollnick SO, Lindenmann J, et al. Photodynamic therapy of non-small cell lung cancer. Narrative review and future directions. Ann Am Thorac Soc. 2016;13(2):265-75. https://doi.org/10.1513/AnnalsATS.201509-650FR.

103. Simone CB, Cengel KA. Photodynamic therapy for lung cancer and malignant pleural mesothelioma. Semin Oncol. 2014;41(6):820-30. https://doi.org/10.1053/j.seminoncol.2014.09.017.

104. Sobhani N, Dolat E, Darroudi M, Hashemzadeh A, Khoobi M, Salarabadi SS, et al. Accompanying photocytotoxic activity of gold nanoechinus and zinc phthalocyanine on cancerous cell lines. Photodiagnosis Photodyn Ther. 2020;32:101929. https://doi.org/10.1016/j.pdpdt.2020.101929.

105. Sobhani N, Sazgarnia A, Rajabi O, Soudmand S, Naghavi N. A study on the photobleaching effect of 5-ALA conjugated gold nanoparticles in a CT26 tumor model during photodynamic therapy. Iran J Med Phys. 2012;9(3):217-24.

106. Sun W, Luo L, Feng Y, Qiu Y, Shi C, Meng S, et al. Gadolinium-rose bengal coordination polymer nanodots for MR-/fluorescenceimage-guided radiation and photodynamic therapy. Adv Mater. 2020;32(23):2000377. https://doi.org/10.1002/adma.202000377.

107. Tanaka T, Matono S, Nagano T, Murata K, Sueyoshi S, Yamana H, et al. Photodynamic therapy for large superficial squamous cell carcinoma of the esophagus. Gastrointest Endosc. 2011;73(1):1-6. https://doi.org/10. 1016/j.gie.2010.08.049.

108. Tang PM-K, Chan JY-W, Au SW-N, Kong S-K, Tsui SK-W, Waye MM-Y, et al. Pheophorbide a, an active compound isolated from Scutellaria barbata, possesses photodynamic activities by inducing apoptosis in human hepatocellular carcinoma. Cancer Biol Ther. 2006;5(9):1111-6. https:// doi.org/10.4161/cbt.5.9.2950.

109. Tardivo JP, Del Giglio A, de Oliveira CS, Gabrielli DS, Junqueira HC, Tada DB, et al. Methylene blue in photodynamic therapy: from basic mechanisms to clinical applications. Photodiagnosis Photodyn Ther. 2005;2(3):175-91. https://doi.org/10.1016/S1572-1000(05)00097-9.

110. Tarstedt M, Gillstedt M, Wennberg Larkö A-M, Paoli J. Aminolevulinic acid and methyl aminolevulinate equally effective in topical photodynamic therapy for non-melanoma skin cancers. J Eur Acad Dermatol Venereol JEADV. 2016;30(3):420-3. https://doi.org/10.1111/jdv.13558.

111. Triesscheijn M, Ruevekamp M, Aalders M, Baas P, Stewart FA. Outcome of $\mathrm{MTHPC}$ mediated photodynamic therapy is primarily determined by the vascular response. Photochem Photobiol. 2005;81(5):1161-7. https://doi.org/10.1562/2005-04-04-RA-474.

112. Usuda J, Kato H, Okunaka T, Furukawa K, Tsutsui H, Yamada K, et al. Photodynamic therapy (PDT) for lung cancers. J Thorac Oncol. 2006;1 (5):489-93.

113. Vegter S, Tolley K. A network meta-analysis of the relative efficacy of treatments for actinic keratosis of the face or scalp in Europe. PLoS ONE. 2014;9(6). https://doi.org/10.1371/journal.pone.0096829 [Accessed 17 Oct 2020].

114. Vijayaraghavan P, Chiang C-S, Chiang HK, Li M-L, Hwang KC. Multibranched plasmonic gold nanoechinus-based triple modal bioimaging: an efficient NIR-to-NIR up and down-conversion emission and photoacoustic imaging. Adv Mater Technol. 2016;1(7):1600107. https://doi.org/ 10.1002/admt.201600107.

115. Vijayaraghavan P, Liu C-H, Vankayala R, Chiang C-S, Hwang KC. Designing multi-branched gold nanoechinus for NIR light activated dual modal photodynamic and photothermal therapy in the second biological window. Adv Mater Deerfield Beach Fla. 2014;26(39):6689-95. https://doi.org/10.1002/adma.201400703.

116. Wang C, Cheng L, Liu Z. Upconversion nanoparticles for photodynamic therapy and other cancer therapeutics. Theranostics. 2013;3(5):317-30. https://doi.org/10.7150/thno.5284.

117. Wang D, Wang H, Ji L, Xu M, Bai B, Wan X, et al. Hybrid plasmonic nanodumbbells engineering for multi-intensified second near-infrared light induced photodynamic therapy. ACS Nano. 2021;15(5):8694-705. https://doi.org/10.1021/acsnano.1c00772.

118. Wang L, Yang H, Li B. Photodynamic therapy for prostate cancer: a systematic review and meta-analysis. Prostate Int. 2019;7(3):83-90. https:// doi.org/10.1016/j.prnil.2018.12.002.
119. Wang M, Chen Z, Zheng W, Zhu H, Lu S, Ma E, et al. Lanthanide-doped upconversion nanoparticles electrostatically coupled with photosensitizers for near-infrared-triggered photodynamic therapy. Nanoscale. 2014;6(14):8274-82. https://doi.org/10.1039/C4NR01826E.

120. Wang S, Chen H, Liu J, Chen C, Liu B. NIR-II light activated photosensitizer with aggregation-induced emission for precise and efficient two-photon photodynamic cancer cell ablation. Adv Funct Mater. 2020;30(30):2002546. https://doi.org/10.1002/adfm.202002546.

121. Wezgowiec J, Derylo MB, Teissie J, Orio J, Rols M-P, Kulbacka J, et al. Electric field-assisted delivery of Photofrin to human breast carcinoma cells. J Membr Biol. 2013;246(10):725-35. https://doi.org/10.1007/ s00232-013-9533-z.

122. Wilson BC, Patterson MS. The physics, biophysics and technology of photodynamic therapy. Phys Med Biol. 2008;53(9):R61-109. https://doi. org/10.1088/0031-9155/53/9/R01

123. Wu H, Minamide T, Yano T. Role of photodynamic therapy in the treatment of esophageal cancer. Dig Endosc. 2019a;31(5):508-16. https:// doi.org/10.1111/den.13353.

124. Yang H, Zhuang J, Li N, Li Y, Zhu S, Hao J, et al. Efficient near-infrared photosensitizer with aggregation-induced emission characteristics for mitochondria-targeted and image-guided photodynamic cancer therapy. Mater Chem Front. 2020a;4(7):2064-71. https://doi.org/10. 1039/D0QM00170H.

125. Yang P-W, Hung M-C, Hsieh C-Y, Tung E-C, Wang Y-H, Tsai J-C, et al. The effects of Photofrin-mediated photodynamic therapy on the modulation of EGFR in esophageal squamous cell carcinoma cells. Lasers Med Sci. 2013a;28(2):605-14. https://doi.org/10.1007/s10103-012-1119-y.

126. Yang Y, Guo Q, Chen H, Zhou Z, Guo Z, Shen Z. Thienopyrrole-expanded BODIPY as a potential NIR photosensitizer for photodynamic therapy. Chem Commun. 2013b;49(38):3940-2. https://doi.org/10.1039/C3CC4 0746B.

127. Yang Z, Yin W, Zhang S, Shah I, Zhang B, Zhang S, et al. Synthesis of AIEactive materials with their applications for antibacterial activity, specific imaging of mitochondrion and image-guided photodynamic therapy. ACS Appl Bio Mater. 2020b;3(2):1187-96. https://doi.org/10.1021/ acsabm.9b01094.

128. Yano T, Hatogai K, Morimoto H, Yoda Y, Kaneko K. Photodynamic therapy for esophageal cancer. Ann Transl Med. 2014;2(3). https://doi. org/10.3978/j.issn.2305-5839.2014.03.01 [Accessed 19 Oct 2020].

129. Yanovsky RL, Bartenstein DW, Rogers GS, Isakoff SJ, Chen ST. Photodynamic therapy for solid tumors: a review of the literature. Photodermatol Photoimmunol Photomed. 2019;35(5):295-303. https://doi.org/10. 1111/phpp.12489.

130. Yuan A, Wu J, Tang X, Zhao L, Xu F, Hu Y. Application of near-infrared dyes for tumor imaging, photothermal, and photodynamic therapies. J Pharm Sci. 2013;102(1):6-28. https://doi.org/10.1002/jps.23356.

131. Zhang L, Gao Y, Sun S, Li Z, Wu A, Zeng L. pH-Responsive metal-organic framework encapsulated gold nanoclusters with modulated release to enhance photodynamic therapy/chemotherapy in breast cancer. J Mater Chem B. 2020a;8(8):1739-47. https://doi.org/10.1039/C9TB0 $2621 \mathrm{E}$.

132. Zhang P, Kuang H, Xu Y, Shi L, Cao W, Zhu K, et al. Rational design of a high-performance quinoxalinone-based AIE photosensitizer for image-guided photodynamic therapy. ACS Appl Mater Interfaces. 2020b;12(38):42551-7. https://doi.org/10.1021/acsami.0c12670.

133. Zhang T, Bao J, Zhang M, Ge Y, Wei J, Li Y, et al. Chemo-photodynamic therapy by pulmonary delivery of gefitinib nanoparticles and 5 -aminolevulinic acid for treatment of primary lung cancer of rats. Photodiagnosis Photodyn Ther. 2020c;31:101807. https://doi.org/10.1016/j.pdpdt. 2020.101807.

134. Zhen S, Yi X, Zhao Z, Lou X, Xia F, Tang BZ. Drug delivery micelles with efficient near-infrared photosensitizer for combined image-guided photodynamic therapy and chemotherapy of drug-resistant cancer. Biomaterials. 2019;218:119330. https://doi.org/10.1016/j.biomaterials. 2019.119330

\section{Publisher's Note}

Springer Nature remains neutral with regard to jurisdictional claims in published maps and institutional affiliations. 